\title{
Coptobrycon bilineatus (Ellis, 1911) (Characiformes: Characidae): redescription and comments on its phylogenetic relationships
}

\author{
Francisco Langeani ${ }^{1}$ and Jane Piton Serra ${ }^{2}$
}

Coptobrycon bilineatus (Ellis, 1911) is redescribed on the basis of specimens from the District of Paranapiacaba, Municipality of Santo André, upper rio Tietê, and additional ones recently collected in a small coastal river system of Serra do Mar, very near the headwaters of the rio Tietê. The genus was compared to other Characidae lacking a supraorbital, and it seems to be more phylogenetically related to Grundulus based on the possession of various putative apomorphic character states related to: the absence of a rhinosphenoid and fourth, fifth (sometimes) and sixth infraorbitals; nasal pores separated; nares with up to six nasal lamellae; cephalic laterosensory system poorly developed on supraorbital and infraorbital series; and a globose scapula. Furthermore, Coptobrycon and Grundulus are characterized by the absence of the adipose fin, of the supraorbital laterosensory series on the parietal, and of the humeral spot, and by the reduction of lateral musculature in front of the first pleural rib and between the first and second pleural ribs. Biogeographic comments are also provided.

Coptobrycon bilineatus (Ellis, 1911) é redescrita com base em exemplares provenientes do Distrito de Paranapiacaba, Município de Santo André, alto rio Tietê, e de um pequeno sistema costeiro da Serra do Mar, muito próximo às cabeceiras do rio Tietê. O gênero foi comparado com outros Characidae sem supraorbital e parece ser mais proximamente relacionado a Grundulus, pela posse de vários estados apomórficos de caracteres: ausência de rinoesfenoide e dos infraorbitais quatro, cinco (eventualmente) e seis; poros nasais separados e não confluentes; narinas com no máximo seis lamelas nasais; sistema látero-sensorial cefálico pouco desenvolvido nas séries supraorbital e infraorbital; e escápula globosa. Adicionalmente, Coptobrycon e Grundulus são também caracterizados pelas: ausências de nadadeira adiposa, da série látero-sensorial cefálica supraorbital e de mácula umeral, e pela redução da musculatura corpórea lateral à frente da primeira costela pleural e entre a primeira e a segunda costelas pleurais. Comentários biogeográficos são também apresentados.

Key words: Grundulus, Phylogeny, Biogeography, Northern Andes, Southeastern Brazil.

\section{Introduction}

Hasemania bilineata was described by Ellis (1911) based on the holotype and eight paratypes from Alto da Serra (Paranapiacaba and Mogi das Cruzes). Later, Géry (1966) erected the genus Coptobrycon for that species, justifying his decision in view of the considerable differences shown by this species when compared to other Hasemania species: "dorsal fin in advance of the middle of the body, a very short lateral line (only 3 perforated scales), a very short anal fin, and chiefly very aberrant mandibular teeth (Parodon-like multicuspid incisors) which number only 3 on each side". Géry (1966: 224) suggested that, contrary to Hasemania, Coptobrycon could be related to the "Hemibryconini," since it displayed some characters commonly found in the latter group, such as four teeth in the inner row of the premaxilla, third infraorbital well developed and, generally, irregularly implanted teeth in the outer row of the premaxilla. More recently, Mirande $(2009,2010)$ suggested a close phylogenetic relationship between Coptobrycon and Grundulus.

Until recently, only a few specimens of Coptobrycon from the upper rio Tietê were known: the type series of Hasemania bilineata, consisting of nine specimens, deposited at FMNH and CAS, plus four specimens in the MZUSP and six at the Museu de História Natural "Prof. Adão José Cardoso" of the Universidade Estadual de Campinas (ZUEC). The recent collection of a large series of Coptobrycon from the rio Itatinga (Serra et al., 2007), a tributary of the rio Itapanhaú, an independent small coastal river system in São Paulo State, prompted a redescription of this monotypic and enigmatic genus.

${ }^{1}$ Universidade Estadual Paulista - UNESP, Departamento de Zoologia e Botânica. Rua Cristóvão Colombo, 2265, 15054-000 São José do Rio Preto, São Paulo, Brazil. langeani@ibilce.unesp.br ${ }^{2}$ Instituto Federal de Educação, Ciência e Tecnologia do Sul de Minas Gerais, Câmpus de Muzambinho, Minas Gerais, Brazil. pitonbio@yahoo.com.br 


\section{Material and Methods}

Counts and measurements followed Fink \& Weitzman (1974), with the following modifications or additions: longitudinal scale rows below lateral line counted to the pelvicfin insertion; scales along the anal-fin base, covering the basal portion of the rays; head depth, measured between the supraoccipital spine and the isthmus; predorsal distance, from the snout tip to the dorsal-fin origin; preventral distance, from the snout tip to the pelvic-fin origin; distance between the pelvic and anal fins, from the pelvic-fin posterior insertion to the anterior portion of the base of the anal fin.

All measurements were taken using an electronic caliper, point-to-point, from the left side of the specimens whenever possible, to the nearest $0.1 \mathrm{~mm}$. In the description, the numbers in parentheses indicate absolute frequency. Specimens were cleared and stained (c\&s) according to Taylor \& van Dyke (1985) and dissected according to Weitzman (1974). Vertebrae (including those four in the Weberian apparatus), gill rakers, branchiostegal rays and small dentary teeth were counted in cleared and stained specimens. Institutional abbreviations followed Reis et al. (2003) with the addition of: Departamento de Zoologia e Botânica, UNESP at São José do Rio Preto (DZSJRP), and the Universidade Estadual de Maringá, Maringá (NUP).

\section{Results}

\section{Coptobrycon Géry, 1966} Figs. 1-7

Coptobrycon Géry, 1966: 226 (type-species: Hasemania bilineata Ellis, 1911, by original designation and monotypy).

Diagnosis. Coptobrycon is easily distinguished from all other Characidae due to: a very peculiar dentary dentition, with only three, large, anterior, multicuspid and pedunculated, principal teeth in each half of the dentary (Fig. 5; vs. four or more conical or cuspidate and not pedunculated teeth, except in the Cheirodontinae and Iguanodectinae, which have more than four pedunculated teeth); the absence of the nasal bone (vs. present); the presence of a straight, dark brown stripe slightly above the base of the anal fin (Fig. 1), from vertical through its origin or slightly behind, continuing through the ventral portion of the caudal peduncle up to the base of the caudal fin (vs. absent). Furthermore, it can also be separated from all other Characidae, except Grundulus, by having the nasal pores separated by a non confluent space (Fig. 2; vs. nasal pores very close and confluent); infraorbitals 4 and 6 (5, sometimes) absent (Fig. 4; vs. present); infraorbital laterosensory canal greatly reduced, with pores inconspicuous or absent (Fig. 4; vs. present); supraorbital laterosensory canal absent in posterior portion of the frontal (vs. present). Other useful diagnostic characters include: up to six olfactory rosette lamellae, turned to the posterior portion of the nasal canal (Fig. 3 ; vs. more than ten lamellae, generally more than fifteen, concentrically arranged; except in Grundulus and Xenurobrycon); adipose fin absent (Fig. 1; vs. present; except in Grundulus, Gymnocharacinus bergi, Hasemania, some Hyphessobrycon species, and Spintherobolus).

\section{Coptobrycon bilineatus (Ellis, 1911) Figs. 1-7}

Hasemania bilineata Ellis, 1911: 150-151 (type locality: “Alto da Serra, São Paulo, in a creek" - São Paulo, upper rio Tietê basin); Eigenmann, 1921: 223-224 (copy of original description); Böhlke, 1958: 45 (compared to Pristicharax hanseni); Géry, 1966: 226-228 (transfer to Coptobrycon); Géry, 1977: 378 and 402 (key, diagnosis and illustration).

Coptobrycon bilineatus. -Géry, 1966: 224-235 (rio Tietê basin, Brazil); Géry, 1972: 9 (citation); Lima \& Gerhard, 2001: 111112 (citation); Géry, 1977: 378 and 402 (key, diagnosis and illustration); Serra et al., 2007: 132, 134, 135, table 1, fig. 3b (rio Itatinga, São Paulo State coastal drainage, RPPN Parque das Neblinas; biogeography; conservation; ecology); Serra et al., 2008: 60-61 (conservation status, ecology, distribution).

Material examined. Brazil. São Paulo. Bertioga. Rio Itatinga, RPPN Parque das Neblinas. DZSJRP 6601, 4, 17.0-26.7 mm SL, near the Visiting Center, at the footbridge, $23^{\circ} 44^{\prime} 55^{\prime}$ 'S $46^{\circ} 09^{\prime} 44^{\prime \prime}$ 'W. DZSJRP 6610, 150, 18.4-36.7 mm SL, and DZSJRP 6889, 2 c\&s, 27.9 and $36.3 \mathrm{~mm}$ SL, under concrete bridge, $2 \mathrm{~km}$ from the Visiting Center, 234' 47.2"S 46009'29.7'W. DZSJRP 6614, 13, 26.7-33.7 mm SL, ca. $9 \mathrm{~km}$ from the Visiting Center, $23^{\circ} 47^{\prime} 42^{\prime \prime S} 46^{\circ} 12^{\prime} 14^{\prime \prime}$ 'W. DZSJRP 6621, 94, 25.7-36.7 mm SL, and DZSJRP 6890, $2 \mathrm{c \& s,} 28.1$ and $36.3 \mathrm{~mm} \mathrm{SL}$, mouth of tributary creek on the right bank of the rio Itatinga, fifth bridge on dirt road from the Visiting Center, $23^{\circ} 47^{\prime} 17.7^{\prime} \mathrm{S} 46^{\circ} 11^{\prime} 26.0^{\prime \prime} \mathrm{W}$. DZSJRP 6624, 1, $27.2 \mathrm{~mm} \mathrm{SL}$, mouth of tributary creek on the right bank of the rio Itatinga, fourth bridge on dirt road from the Visiting Center, 2346 '52.6"S 46 ${ }^{\circ} 10^{\prime} 56.2^{\prime}$ 'W. DZSJRP 6626, 3, 23.2-28.4 mm SL, mouth of tributary creek on the right bank of the rio Itatinga, third bridge on dirt road from the

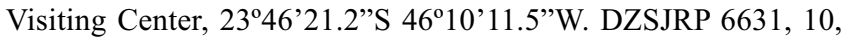
25.7-32.1 mm SL, mouth of tributary creek on the right bank of the rio Itatinga, second bridge on dirt road from the Visiting Center, $23^{\circ} 45^{\prime} 47.6^{\prime} \mathrm{S}$ 4609'41.0'W. DZSJRP 6888, 1 c\&s, $19.3 \mathrm{~mm}$ SL, rio Itatinga, near the Visiting Center, at the footbridge, $23^{\circ} 44^{\prime} 55^{\prime \prime} \mathrm{S}$ 4609'44”W. Santo André. MZUSP 4516, 4, 1 c\&s, 26.6-30.0 mm SL, Campo Grande, near Paranapiacaba.

Diagnosis. The same as for the genus.

Description. Morphometric data in Table 1. Small size, largest specimen examined $37 \mathrm{~mm}$ SL. Body moderately high, greatest body depth slightly ahead vertical through dorsal-fin origin. Dorsal profile of head straight or slightly convex from tip of snout to posterior portion of supraoccipital spine. Dorsal profile of body convex, from supraoccipital spine to dorsalfin origin; straight, or slightly convex, and descending along dorsal-fin base; straight and gradually descending from dorsal fin to caudal peduncle end. Head rounded in transverse 


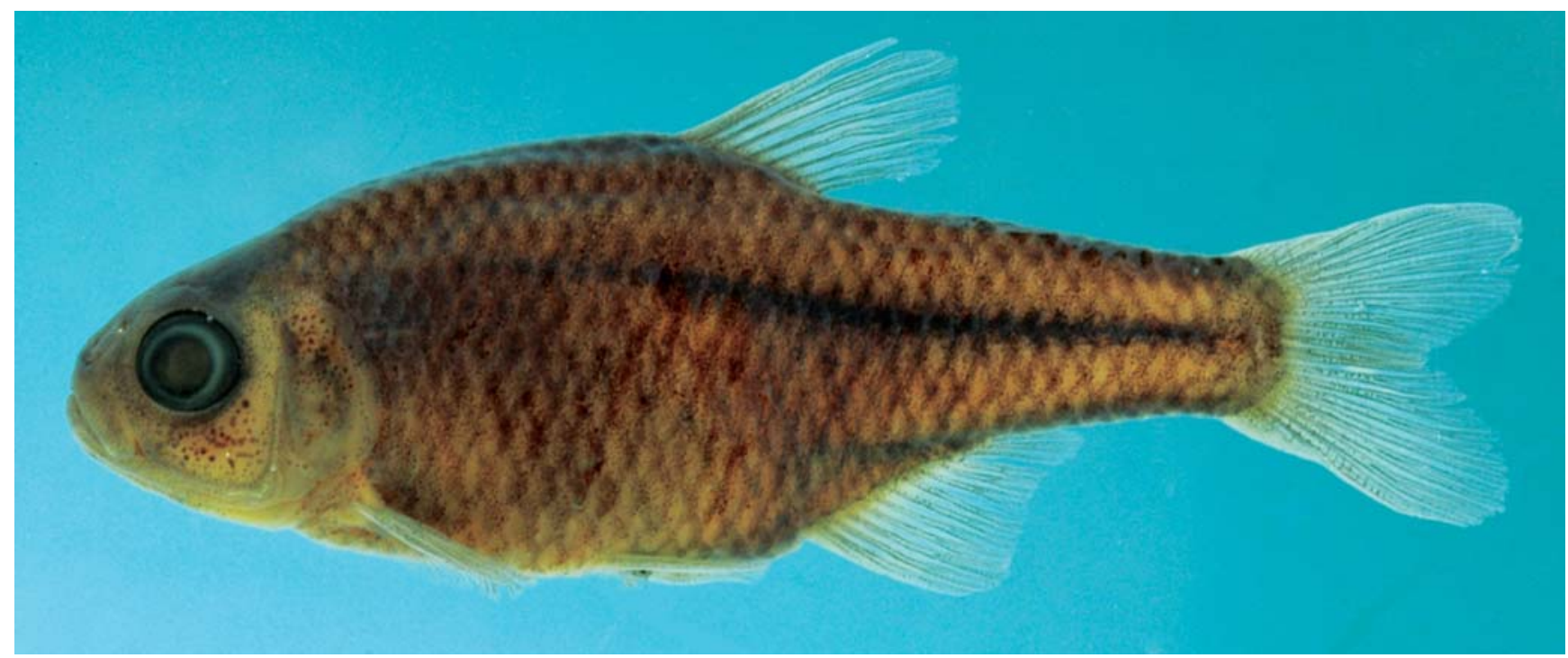

Fig. 1. Coptobrycon bilineatus, DZSJRP 6610, 29.1 mm SL, rio Itatinga, RPPN Parque das Neblinas, Bertioga, São Paulo, Brazil.

section; predorsal portion slightly keeled mainly on posterior half; postdorsal portion slightly flattened anteriorly and slightly keeled posteriorly. Ventral profile of body convex from snout to pelvic-fin origin; straight and horizontal from pelvic fin to anal-fin origin (considerably more convex in specimens with replete digestive tube); straight, or slightly concave, and ascending along anal-fin base; straight and slightly ascending, nearly horizontal, from anal fin to caudal-fin base. Ventral portion of head and body up to anal-fin origin rounded in transverse section; base of anal fin keeled; caudal-peduncle ventral portion rounded, slightly keeled near anal-fin base.

Head triangular from lateral view; snout rounded. Mouth terminal. Premaxilla short; maxilla short, extending to behind vertical passing through anterior margin of orbit. Anterior and posterior nasal pores completely separated (Fig. 2); anterior nasal pore slightly elevated, on apex of short cone, and posterior pore not elevated, at same level of snout surface; olfactory rosette with up to six lamellae, posteriorly directed and turned to posterior nasal pore (Fig. 3). Adipose eyelid underdeveloped, mostly inconspicuous, except in anteroventral portion of eye.

Frontoparietal fontanel from posterior portion of mesethmoid to base of supraoccipital spine, visible and conspicuous in c\&s specimens, but not apparent and covered by thick skin in alcohol-preserved specimens. Rhinosphenoid absent, only cartilaginous tissue present between lateral ethmoid and vomer. Orbitosphenoid with posterior invagination limiting ventral projection, posterior and elongated, turned to pterosphenoid. Fourth and sixth infraorbitals absent; fifth infraorbital also absent in some specimens (Fig. 4); when present, separated from third infraorbital by space equivalent to half its depth (Fig. 4). Nasal and supraorbital absent; antorbital vertically elongated with anteroventral process crossing anterior process of maxilla and turning to premaxilla dorsoposterior portion.
Canals and pores of cephalic lateral line present and well developed along latero-anterior portion of frontal (extending only up to vertical passing through epiphyseal bar), behind anterior nasal pore, on dentary and preopercle; infraorbital bones with canals underdeveloped or absent and inconspicuous pores. Free neuromasts (sensory papillae) present along the supraorbital, infraorbital, maxilla, dentary, gular, and supraoccipital cephalic laterosensory series.

Four branchiostegal rays. Gill rakers elongated on first branchial arch; two on hypobranchial, eight to ten on ceratobranchial and five to six on epibranchial.

Outer row of premaxilla with one tri- to tetracuspid tooth (rarely with more than four cusps), between first and second teeth of inner row and slightly turned anteriorly; inner row with four (33) or five (2) pedunculated, penta- or octocuspid

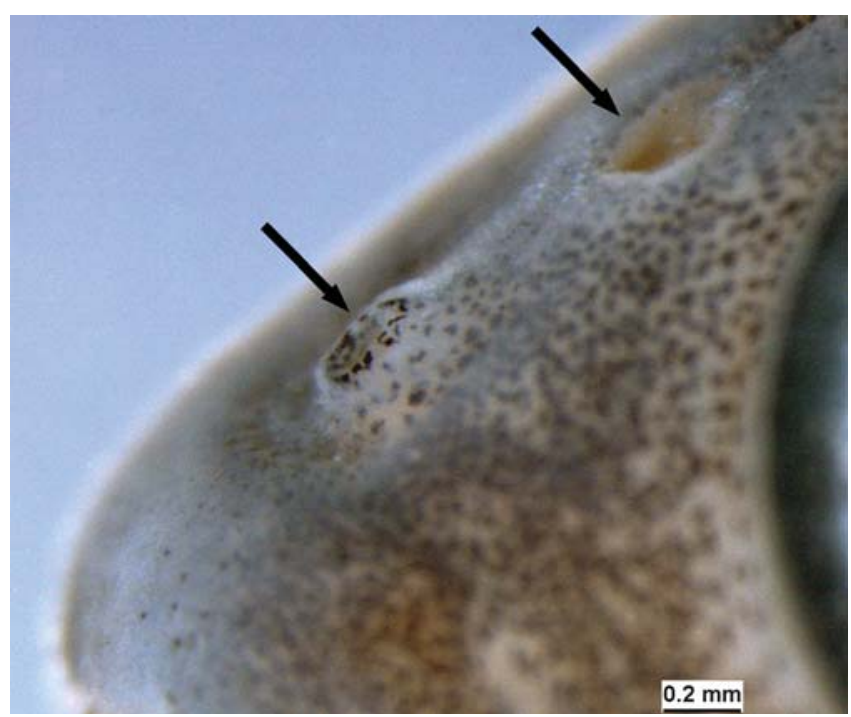

Fig. 2. Coptobrycon bilineatus, DZSJRP 6610, 29.1 mm SL: nasal orifices. 


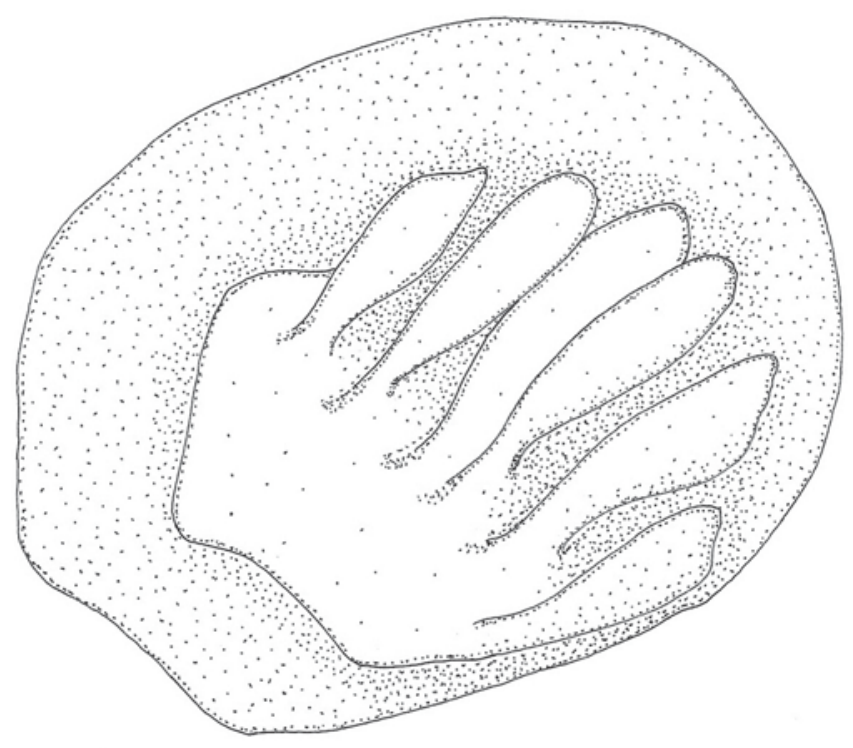

Fig. 3. Coptobrycon bilineatus, DZSJRP 6610, $30.7 \mathrm{~mm}$ SL: olfactory rosettes. Scale bar $=1 \mathrm{~mm}$.

teeth, with wide compressed crown, slightly curved posteriorly, with median cusp subequal, slightly more developed than others (Fig. 5). Maxilla without teeth. Dentary short, with single row of two (2), three (31) or four (2) anterior, large, hepta- to decacuspid, pedunculated teeth, with large, compressed, straight and turned posteriorly crown, with rounded subequal cusps, followed by one to four much smaller conical teeth (Fig. 5). Palatine approximately rectangular, without openings, perforations or thinning in its mid-anterior portion.

Hypaxialis muscle portion largely reduced, especially obliquus superioris muscle, leaving thin muscular layer, composed principally of obliquus inferioris, in front of first pleural rib, exposed anterior and proximally (Fig. 6); muscle reduction also between first and second pleural ribs. No direct contact of swim bladder with skin.

Scales cycloid and relatively large, similar in size to diameter of pupil. Lateral line incomplete, with only two (2), three (20), or four (7) perforated scales, and 26(1), 27(3), 28(6), 29(8), 30(9), 31(1), or 32(2) non-perforated scales. Five (5) or six (26) longitudinal rows of scales above lateral line and four (28) or five (3) below. Two or three scales slightly covering base of first anal-fin rays, visible with high magnification. Twelve (21) or 14(11) scales around caudal peduncle. Predorsal line with regular row of 10(2), 11(4), 12(7), or 13(6) scales. Thirty-two (2), 33 (2) or 34 (1) vertebrae.

Dorsal fin with ii,7(3) or ii,8(30) rays; with posterior rounded edge, in posterior half of body, little behind vertical passing pelvic-fin origin; first unbranched ray almost one-third or half longer than second unbranched one, slightly shorter than first branched ray. Adipose fin absent. Pectoral fin small, with i,8(1), i,9(5), i,10(25), or i,11(2) rays; with posterior rounded edge, not reaching pelvic-fin base, its posterior extremity beyond vertical passing through beginning of last third of distance between its base and pelvic-fin base.

Coracoid little developed ventrally. Opening between coracoid and cleithrum nearly entirely visible laterally; scapula well developed, globose, with small scapular foramen, more central and bordered anteriorly by wide bony portion (Fig. 7). Pelvic fin with i,4(1), i,5(28) or i,6(3) rays; with posterior rounded edge, not reaching anal-fin origin; its posterior extremity beyond vertical passing through last third of distance between its origin and anal-fin origin; anal fin with iii,10(1), iii,11(19), or iii,12(13) rays; with straight or slightly concave edge; second unbranched ray and two first branched rays, longer and subequal, subsequent rays gradually shorter. Caudal fin with rounded lobes and i,17,i(33) principal rays. Mature males and females (dissected from DZSJRP 6610 and 6621) without hooks on pelvic and anal-fin rays.
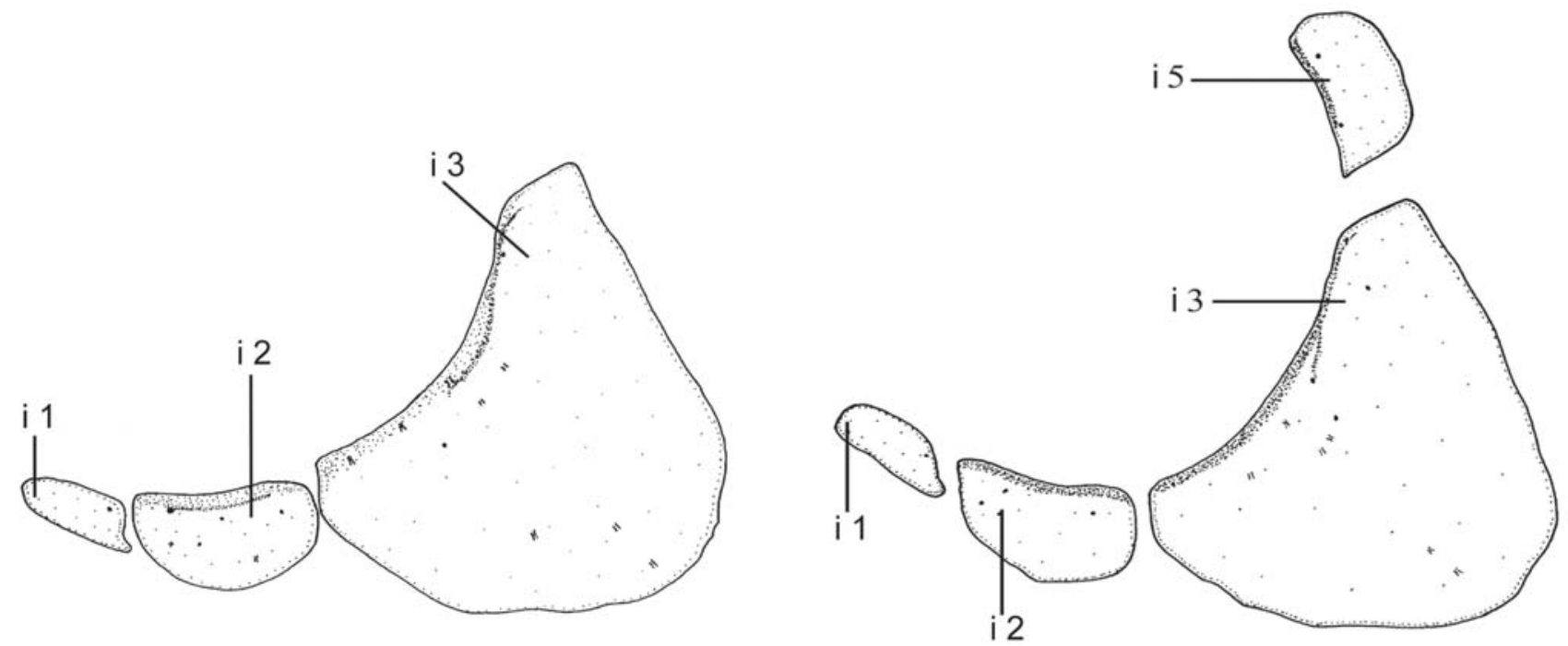

Fig. 4. Coptobrycon bilineatus, infraorbital (i) series, left side, lateral view. DZSJRP 6890, 36.3 mm SL (left), and DZSJRP 6890, $28.1 \mathrm{~mm}$ SL (right). Scale bar $=1 \mathrm{~mm}$. 

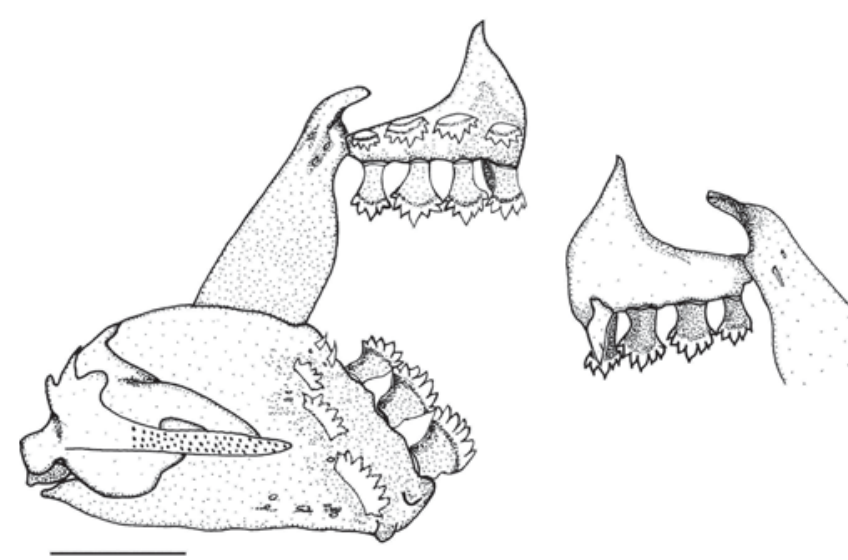

Fig. 5. Coptobrycon bilineatus, DZSJRP 6890, $36.3 \mathrm{~mm} \mathrm{SL}$ premaxillary, maxillary and dentary, left side, medial (left) and lateral views (right). Scale bar $=1 \mathrm{~mm}$.

Color in life. Body predominantly yellowish ventrally. In water, specimens appear golden, probably as a consequence of great quantities of guanine along portions of visceral cavity, infraorbital and opercular regions; lateromedial and lateroventral black conspicuous stripes. Fins yellowish orange, especially dorsal, anal, and caudal fins.

Color in alcohol. Black chromatophores distributed all over body. Head with large concentration of small chromatophores along lateral portion; larger chromatophores on dorsal portion of operculum and below eye, on third infraorbital; regions of larger chromatophores bordered by clear areas, without pigment. Concentrated chromatophores near edges of scales, forming reticulate pattern. Humeral spot absent; mid-lateral stripe from vertical passing dorsal-fin origin, or posterior portion of head (more melanic specimens), up to caudal-fin base; shorter stripe, slightly above anal-fin base, from analfin origin, or little behind, through ventral portion of caudal peduncle up to caudal-fin base; caudal-fin base dark. Dorsal portion of body dark from head to caudal fin; head chromatophores small and numerous; from head to dorsal-fin origin as in rest of body; posterior to dorsal fin much more numerous, larger, conspicuous, and visible laterally. Ventral portions of head and body lighter, with small and numerous chromatophores along dentary, anterior portion of isthmus, and ventral portion of preopercle and interopercle; chromatophores slightly larger and more scattered from posterior portion of head to pelvic-fin origin, and numerous, dense and conspicuous from anal pore to caudal fin. Fins slightly dark, mainly along anterior and posterior edges of rays.

Distribution. Upper rio Tietê (upper rio Paraná drainage) and rio Itatinga, a tributary of the rio Itapanhaú, a small independent coastal river system, São Paulo State, Brazil (Fig. 8).

Ecology and conservation. The RPPN Parque das Neblinas is a privately owned conservation unit within the Atlantic Forest, and most of the rio Itatinga basin is within the

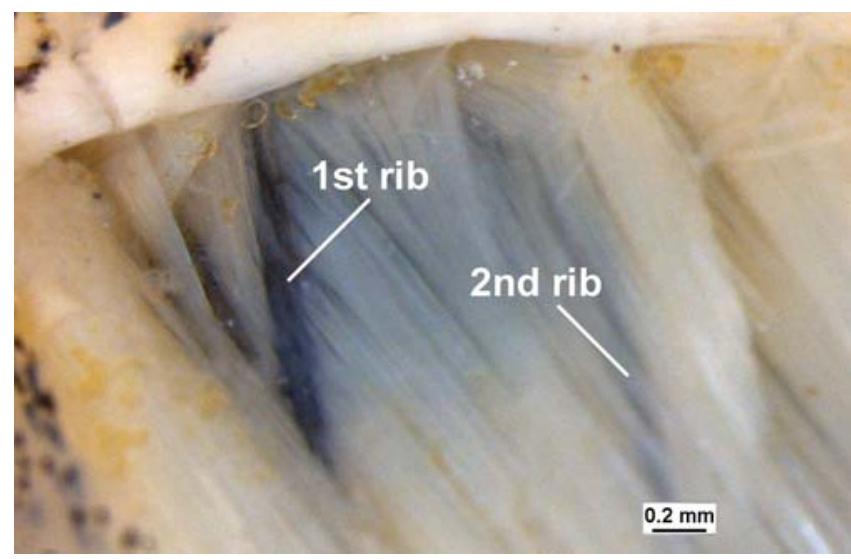

Fig. 6. Coptobrycon bilineatus, DZSJRP 6610,30.7 mm SL: humeral region with tegument removed, showing reduced muscular tissue in front of first pleural rib and between first and second pleural ribs.

boundaries of this protected area. The rio Itatinga (Fig. 9) is a typical Atlantic Forest stream, possessing swift-flowing, transparent, cold waters, and alternating relatively deep pools and shallow riffles. Usually, the bottom of the more lotic portions is composed of sand, stones and boulders, whereas in the more lentic stretches there is an accumulation of leaves and branches from the riparian vegetation. The riparian vegetation is an old, abandoned eucalyptus plantation, with dense undergrowth of native shrubs and trees.

Coptobrycon bilineatus was common and abundant in most of the sampled stretches of the rio Itatinga. Specimens were easily observed forming large schools, often associated with schools of Astyanax paranae. The species was generally recorded in areas with a relatively slow water flow, among macrophytes, branches and submerged logs. The examination of some stomach contents revealed mainly fragmented terrestrial vegetation, although some digested items of animal origin were recorded in smaller quantities. Immature, maturing, mature, and empty gonads were recorded, which seems to indicate that the species reproduces in more than one season of the year. Other species collected at the rio Itatinga are Astyanax paranae, Glandulocauda melanogenys $[=G$. melanopleura Ellis, 1911 sensu Menezes \& Weitzman, 2009], Taunaya bifasciata, Trichomycterus sp. [= T. iheringi (Eigenmann, 1917)], Pseudotocinclus tietensis, and Phalloceros caudimaculatus [=P. reisi Lucinda, 2008] (Serra et al., 2007).

Until recently, Coptobrycon bilineatus was considered to be endemic to the upper course of the rio Tietê (Langeani, 1989), where it was collected for the last time in 1981 (ZUEC 4287). Extensive collecting in the upper rio Tietê basin, conducted from 1985 to date was not successful in finding any additional specimens of the species. Coptobrycon bilineatus is officially considered an endangered species in Brazil (Serra et al., 2008). The discovery of Coptobrycon bilineatus in the rio Itatinga is, from a conservation point of view, quite reassuring. However, its overall conservation status is still cause for concern and special attention to the species is required. 


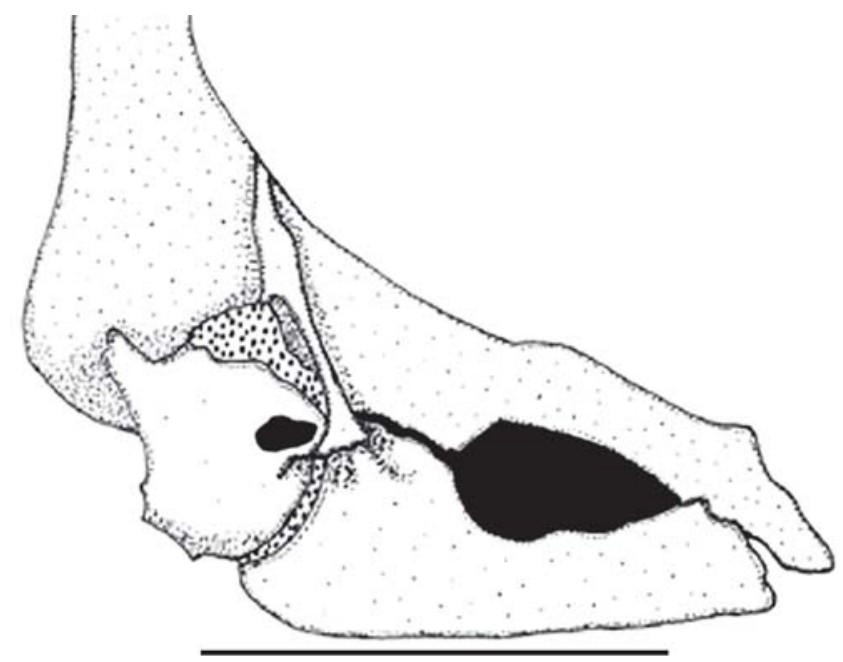

Fig. 7. Coptobrycon bilineatus, DZSJRP 6890, $36.3 \mathrm{~mm}$ SL: pectoral girdle, medial, partial view. Scale bar $=1 \mathrm{~mm}$.

\section{Discussion}

Although there has been recent progress in clarifying phylogenetic relationships within the Characidae (Calcagnotto et al., 2005; Mirande, 2009, 2010; Javonillo et al., 2010), there are still many limitations to a deeper and complete understanding of characid phylogeny, principally due to the enormous diversity of the group (Weitzman \& Malabarba, 1998; Malabarba \& Vari, 2000; Lima et al., 2003), with some species and genera poorly represented in collections and still some with great morphological modifications.

Weitzman \& Malabarba (1998) and Malabarba \& Weitzman (2003) suggest that the absence of a supraorbital would define a monophyletic subgroup within the Characidae. This limitation would restrict the group to the Aphyocharacinae, Cheirodontinae, Characinae, Iguanodectinae, Rhoadsiinae, Stethaprioninae, and "Tetragonopterinae" (sensu Géry, 1977), plus some other genera of uncertain relationship, a group similar to the clade 188 of Mirande (2009) and the clade 189 of Mirande (2010), which also includes the "Bryconops clade," both composing a set formed in part by those previously considered by Géry (1977) in the Characidae, herein Characidae sensu strictu. Coptobrycon was included in this less inclusive group of Malabarba \& Weitzman (2003) and Mirande (2009, 2010).

Previous studies concerning Coptobrycon and Grundulus never addressed their close relationship, proposing Grundulus as closely related to Spintherobolus (Eigenmann, 1915; Géry, 1971, 1977), which was later rejected by Weitzman \& Malabarba (1999), or Coptobrycon as closely related to the Hemibryconini (Géry, 1966), an equivalent to Clade A of Malabarba \& Weitzman (2003), a proposition also rejected by the same authors. These two genera are, in consequence, considered taxa incertae sedis in the Characidae (Lima et al., 2003). More recently, Mirande $(2009,2010)$ presented the most complete characid phylogeny to date, and suggested that the genus Coptobrycon should be classified within the subfamily Gymnocharacinae, resurrected
Table 1. Morphometric data of Coptobrycon bilineatus.

\begin{tabular}{lcccc}
\hline Character & $\mathrm{N}$ & Range & Mean & SD \\
\hline Standard length (mm) & 33 & $25.2-37$ & 31.1 & 3.1 \\
& Percents of Standard length & & \\
Body depth & 33 & $28-35.7$ & 32.3 & 1.7 \\
Head length & 33 & $25.6-28.6$ & 27.2 & 0.8 \\
Predorsal distance & 33 & $37.9-56.6$ & 52.8 & 3.2 \\
Preventral distance & 33 & $32.2-49.7$ & 46.1 & 2.8 \\
Pelvic-anal fin distance & 33 & $14.2-19.7$ & 16.7 & 1.2 \\
Caudal-peduncle depth & 33 & $11.1-14.6$ & 12.8 & 0.7 \\
Dorsal-fin base length & 33 & $12.3-17.1$ & 13.8 & 0.9 \\
Anal-fin base length & 33 & $15.9-21.9$ & 18.6 & 1.3 \\
Pectoral fin length & 33 & $13-18.8$ & 15.6 & 1.3 \\
Pelvic fin length & 33 & $11.9-16.2$ & 13.5 & 1.0 \\
Dorsal fin length & 33 & $21.6-28.2$ & 24.5 & 1.7 \\
Anal fin length & 33 & $16.4-23.3$ & 18.9 & 2.2 \\
& 33 & $75-88.4$ & 82.6 & 3.5 \\
Head depth & Percents of Head length & & \\
Orbital diameter & 33 & $33.3-42.2$ & 37. & 2.4 \\
Snout length & 33 & $20.7-28.6$ & 24.6 & 2.1 \\
Interorbital distance & 33 & $27-34.1$ & 30.3 & 1.8 \\
\hline
\end{tabular}

and redefined to include: Coptobrycon, Grundulus, Gymnocharacinus Steindachner, and Nematobrycon Eigenmann. The Gymnocharacinae, according to Mirande (2010), share the following synapomorphies: denticles on gill rakers absent (character 210: 1); bony hooks on fin rays absent (307: 0); adipose fin absent (356: 1). We found, as in Mirande (2009, 2010), that Coptobrycon is more closely related to Grundulus. The characters, old and new, supporting this close phylogenetic relationship are discussed below.

Nasal pores separated by a non confluent space (Fig. 2) (Mirande, 2010; character 351: 1). The presence of anterior and posterior nasal pores very close and confluent is a plesiomorphic condition in the Characidae. Coptobrycon and Grundulus, nevertheless, have anterior and posterior nasal pores individualized, separated by a space, and non confluent. Anostomids (pers. obs.) and crenuchids are the only other Characiformes having nasal pores separated and non confluent. Buckup (1993a: 233) commented that the separation of nasal pores in the Crenuchidae, as in a few other Characiformes (not listed), would be usually associated with miniaturization.

Few olfactory rosette lamellae turned to the posterior portion (Fig. 3). The olfactory rosette in the Characidae, and in most Characiformes, usually have more than ten lamellae (generally more than fifteen), concentrically arranged (pers. obs.). Coptobrycon and Grundulus, nevertheless, have up to six lamellae, turned to the posterior portion of the nasal canal. Similar conditions also occur in Xenurobrycon and Pyrrhulina, here interpreted as independent acquisitions, since Xenurobrycon is a highly derived member of the subfamily Glandulocaudinae (Weitzman \& Fink, 1985), currently considered a clade within the Stervardiinae (Mirande, 2009, 2010), while the lebiasinid Pyrrhulina is even more distantly related, belonging to a monophyletic clade that includes the Lebiasinidae, Erythrinidae, Hepsetidae and Ctenoluciidae (Vari, 1995), absent in Coptobrycon and Grundulus. 
Rhinosphenoid absent. Coptobrycon and Grundulus show no rhinosphenoid bone and the small space between the orbitospheroid and the midposterior portion of the lateral ethmoid and vomer is filled with a cartilaginous tissue. Among the Characidae sensu stricto most of the included taxa have a rhinosphenoid; the loss of this bone is secondary apomorphic. It was also observed by us in Carlastyanax aurocaudatus and Hasemania crenuchoides, and according to Chernoff \& Machado-Allison (1990), in all species of Ceratobranchia and Astyanax festae, an unidentified Creagrutus species, and in some species of Bryconamericus. Gymnocharacinus bergii also does not have a rhinosphenoid (Miquelarena \& Arámburu, 1983). The absence of the rhinosphenoid was proposed by Mirande (2010, character 47: 0 ) as a synapomorphy for the clade 280 , including Gymnocharacinus, Coptobrycon, and Grundulus.

Infraorbital laterosensory canal underdeveloped or absent. In the Characidae, infraorbitals 1 to 6 show a conspicuous laterosensory canal. In Coptobrycon and Grundulus, this canal is greatly reduced, with pores inconspicuous or absent.

Infraorbitals 4, 5, and 6 absent (Fig. 4). The Characidae usually have six infraorbitals and the loss or reduction of any of them is frequently associated with small size or miniaturization (Weitzman \& Fink, 1983, 1985). Infraorbitals 4 and 6 are always, and 5 eventually, absent in Coptobrycon and Grundulus.

Supraorbital laterosensory canal partially absent in frontal and totally absent in parietal. The supraorbital laterosensory canal frequently extends up to the parietal; its absence in that

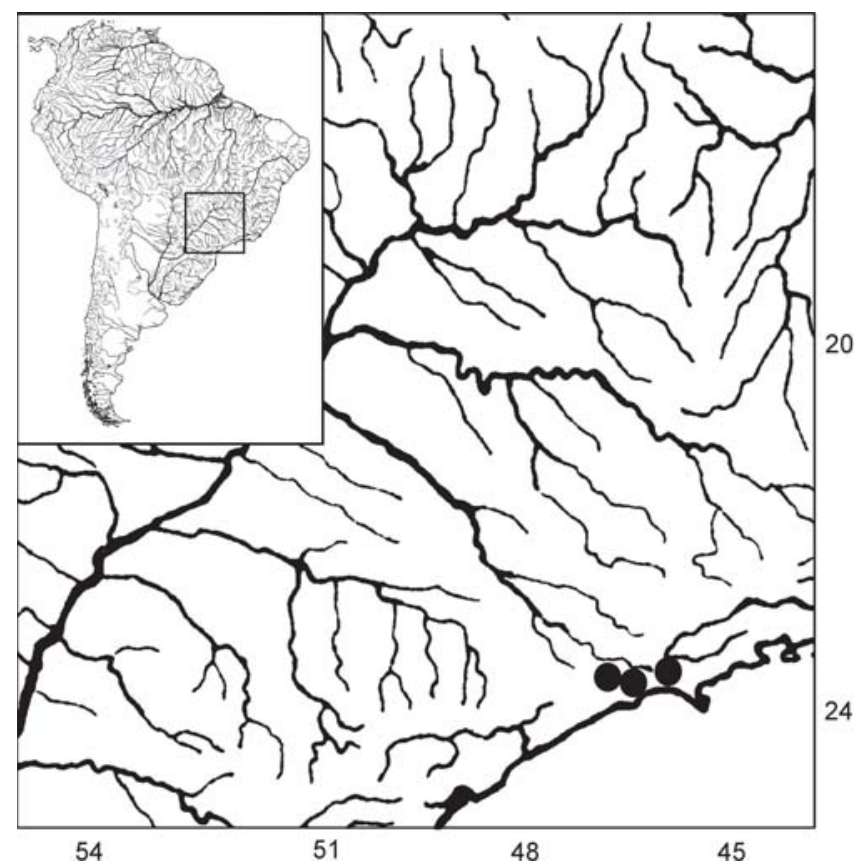

Fig. 8. Geographic distribution of Coptobrycon bilineatus. Each dot may represent more than one locality. bone is apomorphic within Characiformes and related to a miniaturization phenomenon (Buckup, 1993b), which may, nevertheless, also occur in normal-sized non-miniature species (Zanata \& Vari, 2005). In our analysis, the supraorbital laterosensory canal in Grundulus and Coptobrycon, apart from being absent in the parietal, also does not occur in the posterior portion of the frontal.

Scapula globose, with a wider anterior edge and reduced foramen (Fig. 7). The main body of the scapula in the Characidae has an hourglass shape, with dorsal and ventral, narrow and anterior, projections fused anteriorly, forming a large bone ring which borders the scapular foramen (Weitzman, 1962: 41, fig. 20). In Coptobrycon and Grundulus, and also in Markiana, Metynnis and Triportheus, the scapula is more globose; the scapular foramen is reduced and the bone ring wider. This is probably apomorphic, albeit not homologous for all those taxa, since both Metynnis and Triportheus are not part of the Characidae sensu strictu because they have a supraorbital and share with other Serrasalminae (Machado-Allison, 1983; Mirande, 2009), the first, and Lignobrycon (Malabarba, 1998) and Brycon (Mirande, 2009, who did not examine Lignobrycon), the second, other apomorphic states absent in Coptobrycon and Grundulus. Markiana is according to Mirande (2009) included in his Astyanax clade, with various Astyanax species, and some of Hyphessobrycon, Bryconamericus, and Psellogrammus.

A similar scapula also occurs in Lepidarchus (Alestidae), as referred to by Zanata \& Vari (2005: 62), and Spintherobolus, as illustrated in Weitzman \& Malabarba (1999: Fig. 18); this last genus shares with the rest of the Cheirodontinae various apomorphies absent in Coptobrycon and Grundulus.

Mirande (2010) also proposed as synapomorphies uniting Coptobrycon and Grundulus: laterosensory canal of dentary reduced or absent (79:1) and lateral line interrupted (91:1), character-states also occurring independently in other characids.

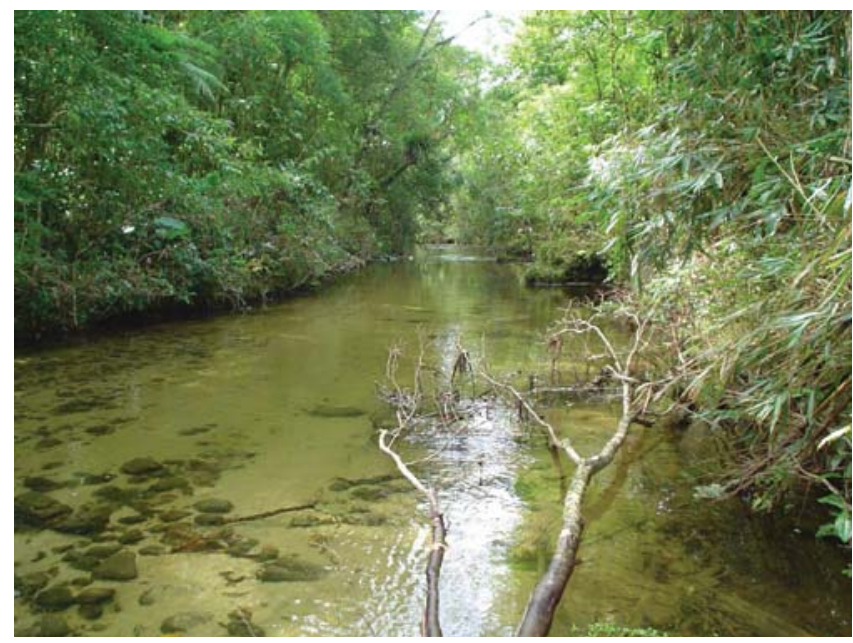

Fig. 9. Rio Itatinga, affluent to the rio Itapanhau, Bertioga, SP. 
Finally, the four teeth in the inner row of the premaxilla and ii, 7-8 rays in the dorsal fin, features shown by Coptobrycon, should be interpreted as an independent offshoot from similar conditions in the members of the socalled Characidae Clade A of Malabarba \& Weitzman (2003) (= Stervardiinae sensu Mirande, 2009, 2010). In contrast to the taxa belonging to that clade, Coptobrycon has a postcleithrum 3 with a posterior convex projection ( $v s$. simple), palatine without openings, perforation or thinning in its midanterior portion ( $v s$. normally present), orbitosphenoid with a ventral and posterior invagination ( $v s$. absent) and humeral spot absent ( $v s$. normally present).

Biogeography. Coptobrycon and Grundulus, occurring respectively in the eastern Brazilian Shield and Colombian Andes, would fit better in the "Pattern A" of Ribeiro (2006), a consequence of ancient events, which resulted in sistertaxa geographically restricted and very distant from each other. The restricted occurrences of Coptobrycon and Grundulus only in the the Serra do Mar and,the highlands of the Andes, leaving a large area in the central portion of South America which lacks records of both genera, lead us to hypothesize a relictual pattern of occurrence for the clade that, probably, underwent a process of extinction in the lowland drainages (Román-Valencia et al., 2003, for Grundulus) situated in between, similar to the proposition of Bührnheim et al. (2008) for the distribution of the monophyletic clade composed of Spintherobolus and Amazonspinther (Cheirodontinae, Characidae). Furthermore, extinction seems to be currently threatening the clade; Coptobrycon bilineatus and Grundulus species are considered endangered (Román-Valencia et al., 2003, 2005; Serra et al., 2008, respectively), similar to the situation for Spintherobolus, as already addressed by Bührnheim et al. (2008).

In spite of their restricted geographic distribution, recent surveys in the northern Andes and Serra do Mar, respectively, have uncovered new species of Grundulus (Román-Valencia et al., 2003, 2005) and enlarged the area of distribution of Coptobrycon bilineatus (Serra et al., 2007), suggesting the possibility of discovering other new taxa, which may provide more information on the clade.

Serra et al. (2007) suggested that the occurrence of Coptobrycon bilineatus together with Glandulocauda melanogenys $[=$ G. melanopleura (Ellis, 1911) sensu Menezes \& Weitzman, 2009], Pseudotocinclus tietensis, and Astyanax paranae, in a coastal drainage of the São Paulo State, was due to headwater capture of the upper Tietê by the rio Itatinga, similar to what happened in other drainages in that part of southeast Brazil (see Ribeiro et al., 2006, for a description of the tectonic processes and additional examples). Moreover, this discovery reinforces the statement made by Oliveira \& Britski (2000) that a greater number of species endemic to the upper Tietê, as proposed by Langeani (1989), possibly occur in other drainage areas of southeast Brazil.
Comparative material. Aphyocharax anisitsi, DZSJRP 4763, 1, $23.8 \mathrm{~mm}$ SL. Aphyocharax dentatus, DZSJRP 2857, 5, 20.3-52.1 mm SL. Aphyocharax sp., DZSJRP 2984, 4, 52.6-63.7 mm SL. Astyanax fasciatus, DZSJRP 3580, 2 c\&s, 45.0-53.4 mm SL. Astyanax janeiroensis, DZSJRP 2289, 5, 57.2-73.1 mm SL. Astyanax paranae, DZSJRP 2255, 2, 17.2-44.6 mm SL. Brycon orthotaenia, DZSJRP 2392, 1, 143.4 mm SL. Bryconamericus exodon, MZUSP 28026, 1 c\&s, 43.1 mm SL. Bryconamericus sp., DZSJRP 3022, 116, 4 c\&s, 20.7-47.2 mm SL; DZSJRP 5534, 50, 33.4-57.2 mm SL. Bryconops melanurus, DZSJRP 6648, 1, $79.5 \mathrm{~mm}$ SL. Bryconops sp., DZSJRP 3804, 2 c\&s, 55.7-75.4 mm SL. Carlastyanax aurocaudatus, DZSJRP 6638, 4, 1 c\&s, 35.0-47.8 mm SL. Characidium gomesi, DZSJRP 2319, 1 c\&s, 48 mm SL. Cheirodon stenodon, DZSJRP 3743, 1 c\&s, 29 mm SL. Creagrutus brevipinnis, DZSJRP 6637, 2, 41.6-46.6 mm SL. Creagrutus britskii, MZUSP 55232, 2 c\&s, 35.1-38.6 mm SL. Bryconops affinis, DZSJRP 2431, 1, $95.5 \mathrm{~mm}$ SL. Ctenobrycon alleni, DZSJRP 2804, 12, 66.3-84.1 mm SL. Ctenobrycon hauxwellianus, DZSJRP 2803, 11, 2 c\&s, 29.6-39.6 mm SL. Deuterodon langei, DZSJRP 5727, 8, 72.9-93.1 mm SL. Deuterodon pedri, DZSJRP 3705, 1, 1 c\&s, 37.9-49.3 mm SL. Exodon paradoxus, DZSJRP 3901, 9, 2 c\&s, 43.1-68.4 mm SL. Glandulocauda melanopleura, DZSJRP 6613, 2, 28.0-28.3 mm SL. Grundulus bogotensis, DZSJRP 7499, 3, 1 c\&s, 22.0-23.4 mm SL. Grundulus cochae, DZSJRP 7498, 3 paratypes, 1 c\&s, 31.3-34.0 mm SL. Gymnocorymbus ternetzi, DZSJRP 2808, 25, 2 c\&s, 31.3-38.0 mm SL. Hasemania crenuchoides, MZUSP 52732, holotype, $63.7 \mathrm{~mm}$ SL; DZSJRP 11039, 47, 4 c\&s, 29.6-41.5 mm SL. Hasemania hanseni, MZUSP 35676, 268, 2 c\&s, 21.8-33.0 mm SL. Hasemania sp., DZSJRP 5581, 37, 3 c\&s, 9.6-29.2 mm SL; MZUSP 35676, 40 of 268, 2 c\&s, 21.8-33 mm SL; NUP 835, 49, 2 c\&s, 16.8-28.8 mm SL. Hemibrycon boquiae, DZSJRP 6636, 4, 1 c\&s, 52.0-73.0 mm SL. Hemigrammus marginatus, DZSJRP 328, 22, 11.6-29.4 mm SL. Hemigrammus unilineatus, MZUSP 65409, 15 of 31, 2 c\&s, 14.5$28.1 \mathrm{~mm}$ SL. Hollandichthys multifasciatus, DZSJRP 5724, 1, 50.4 mm SL. Odontostilbe sp., DZSJRP 4300, 8, 1 c\&s, 26.4-29.8 mm SL. Hoplias malabaricus, DZSJRP 7189, 2 c\&s, 70.1 and $84.6 \mathrm{~mm}$ SL. Hyphessobrycon anisitsi, DZSJRP 2256, 3, 29.7-57.9 mm SL. Hyphessobrycon bifasciatus, DZSJRP 5718, 21, 16.2-36.6 mm SL. Hyphessobrycon eques, DZSJRP 4754, 84, 15.2-31.4 mm SL. Hyphessobrycon heliacus, DZSJRP 3071, 25, 22.3-29.5 mm SL. Hyphessobrycon langeanii, DZSJRP 4212, 23, 17.8-29.9 mm SL. Hyphessobrycon negodagua, MZUSP 54589, 20 of 103, 4 c\&s, 21.7-28.8 mm SL. Hyphessobrycon reticulatus, DZSJRP 6205, 27, 18.8-38.2 mm SL. Iguanodectes geisleri, DZSJRP 3036, 1, 128.6 mm SL. Jupiaba acanthogaster, DZSJRP 5342, 4, 2 c\&s, 50.9-52.7 mm SL. Jupiaba sp., DZSJRP 5344, 10, 30.6-38.9 mm SL. Knodus breviceps, DZSJRP 6659, 11, 46.7-69.3 mm SL. Knodus chapadae, DZSJRP 5346, 3, 50.2-54.0 mm SL. Knodus moenkhausii, DZSJRP 4980, 74, 23.9-39.0 mm SL. Markiana nigripinnis, DZSJRP 355, 2 c\&s, 46.6-58.0 mm SL. Metynnis maculatus, DZSJRP 5499, 2 c\&s, 35.7-42.4 mm SL. Mimagoniates microlepis, DZSJRP 5455, 66, 2 c\&s, 11.7-42.8 mm SL. Moenkhausia intermedia, DZSJRP 2228, 12, 23.7-25.2 mm SL. Odontostilbe microcephala, DZSJRP 3055, 8, 48.4-61.1 mm SL. Odontostilbe sp., DZSJRP 4274, 1, $29.7 \mathrm{~mm}$ SL. Odontostoechus lethostigmus, DZSJRP 7071, $1 \mathrm{c} \& \mathrm{~s}, 37.4 \mathrm{~mm}$ SL. Oligosarcus sp., DZSJRP 5158, 3, 32.7-43.9 mm SL. Parapristella aubynei, MZUSP 17718, 7, 1 c\&s, 23.1-26.2 mm SL. Parapristella georgiae, MCP 14922, 8, 1 c\&s, 28.4-36.4 mm SL. Piabina argentea, DZSJRP 3709, 4, 52.6-73.8 mm SL; DZSJRP 6684, 6, 37.6-53.8 mm SL. Piabucus melanostomus, DZSJRP 620, 15, 1 c\&s, 75.0-95.6 mm SL. Planaltina britskii, DZSJRP 6399, 7, 
16.8-29.3 mm SL. Poptela paraguayensis, DZSJRP 627, 2 c\&s, 40.0-43.2 mm SL. Probolodus heterostomus, DZSJRP 2315, 1, 64.7 mm SL. Pyrrhulina australis, DZSJRP 5107, 2 c\&s, 32.3-33.4 mm SL. Rhinobrycon negrensis, MZUSP 27100, 2 c\&s, 29.5-32.1 $\mathrm{mm}$ SL. Roeboides bonariensis, DZSJRP 536, 6, 51.8-86.7 mm SL. Roeboides descalvadensis, DZSJRP 4761, 218, 23.1-41.5 mm SL. Salminus hilarii, DZSJRP 3833, 1 c\&s, 70.0 mm SL. Serrapinnus heterodon, DZSJRP 2012, 69, 2 c\&s, 23.2-35.9 mm SL. Serrapinnus notomelas, DZSJRP 4883, 141, 21.2-31 mm SL; DZSJRP 6817, 2 , 23.6-28.6 mm SL. Serrasalmus maculatus, DZSJRP 1003, $1 \mathrm{c} \& \mathrm{~s}$, $47.4 \mathrm{~mm}$ SL. Spintherobolus papilliferus, DZSJRP 2244, 1, $48.7 \mathrm{~mm}$ SL. Tetragonopterus argenteus, DZSJRP 5338, 1, $64.4 \mathrm{~mm} \mathrm{SL}$. Thayeria obliqua, MZUSP 29391, 9 of 43, 2 c\&s, 28.4-37.5 mm SL. Triportheus sp., DZSJRP 4298, 1 c\&s 55.0 mm SL.

\section{Acknowledgements}

We thank Fernando Carvalho (UFRGS) and Henrique Chaves for their help with the field collections and Lilian Casatti for her analysis of the gut contents. We are grateful to Osvaldo T. Oyakawa (MZUSP), Carlos A. S. Lucena and Zilda M. S. Lucena (MCP), and Carla S. Pavanelli (NUP) for making available some specimens under their care, and to César Román-Valencia (Universidad del Quindio, Colombia) for the donation of the Grundulus specimens. The Instituto de Pesquisas Ecológicas (IPÊ) and Instituto Ecofuturo are acknowledged for authorizing the collections, financial support and lodging. This work was further funded by FAPESP (process 04/00545-8, FL) and CNPq (processes 140465/2006-5, JPS; 306988/2008-9, FL). Three reviewers made valuable suggestions and comments.

\section{Literature Cited}

Böhlke, J. 1958. Studies on fishes of the family Characidae, $\mathrm{n}^{\circ} 14$. A report on several extensive recent collections from Ecuador. Proceedings of the Academy of Natural Sciences of Philadelphia, 110(1): 121p.

Buckup, P. A. 1993a. The monophyly of the Characidiinae, a Neotropical group of characiform fishes (Teleostei: Ostariophysi). Zoological Journal of the Linnean Society, 108: 225-245.

Buckup, P. A. 1993b. Phylogenetic interrelationships and reductive evolution in neotropical characidiin fishes (Characiformes, Ostariophysi). Cladistics, 9: 305-341.

Calcagnotto, D., S. A. Schaefer \& R. DeSalle. 2005. Relationships among characiform fishes inferred from analysis of nuclear and mitochondrial gene sequences. Molecular Phylogenetics and Evolution, 36: 135-153.

Chernoff, B. \& A. Machado-Allison. 1990. Characid fishes of the genus Ceratobranchia, with descriptions of new species from Venezuela and Peru. Proceedings of the Academy of Natural Sciences of Philadelphia, 142: 261-290.

Ellis, M. D. 1911. On the species of Hasemania, Hyphessobrycon, and Hemigrammus collected by J. D. Haseman for the Carnegie Museum. Annals of the Carnegie Museum, 8: 148-163.

Eigenmann, C. H. 1915. The Cheirodontinae, a subfamily of minute characid fishes of South America. Memoires of the Carnegie Museum, 7: 1-99.

Eigenmann, C. H. 1921. The American Characidae (3). Memoires of the Museum of Comparative Zoology, 43: 209-310.
Fink, W. L. \& S. H. Weitzman. 1974. The so-called Cheirodontin fishes of Central America with descriptions of two new species (Pisces: Characidae). Smithsonian Contributions to Zoology, 172: 1-46.

Géry, J. 1966. A review of certain Tetragonopterinae (Characoidei), with the description of two new genera. Ichthyologica - The Aquarium Journal, 37: 211-235.

Géry, J. 1971. Une sous-famille nouvelle de poissons characoides sud-américains : les Geisleriinae. Vie Millieu, 22(1) : 153-166.

Géry, J. 1972. Corrected and supplemented descriptions of certain characoid fishes described by Henry W. Fowler, with revisions of several of their genera. Studies on the Neotropical Fauna, 7: $1-35$.

Géry, J. 1977. Characoids of the world. New Jersey, Neptune City, T. F. H. Publications, 672p.

Javonillo, R., L. R. Malabarba, S. H. Weitzman \& J. R. Burns. 2010. Relationships among major lineages of characid fishes (Teleostei: Ostariophysi: Characiformes), based on molecular sequence data. Molecular Phylogenetics and Evolution, 54: 498-511.

Langeani, F. 1989. Ictiofauna do alto curso do rio Tietê (SP): Taxonomia. Unpublished Ph.D. Dissertation. Universidade de São Paulo, São Paulo, 231p.

Lima, F. C. T. \& P. Gerhard. 200. A new Hyphessobrycon (Characiformes: Characidae) from Chapada Diamantina, Bahia, Brazil, with notes on its natural history. Ichthyological Exploration of Freshwaters, 12: 105-114.

Lima, F. C. T., L. R. Malabarba, P. A. Buckup, J. F. Pezzi da Silva, R. P. Vari, A. Harold, R. Benine, O. Oyakawa, C. S. Pavanelli, N. A. Menezes, C. A. S. Lucena, M. C. S. L. Malabarba, Z. M. S. Lucena, R. E. Reis, F. Langeani, L. Casatti, V. A. Bertaco, C. Moreira \& P. H. F. Lucinda. 2003. Genera Incertae sedis in Characidae. Pp. 106-169. In: Reis, R. E., Kullander, S. O. \& Ferraris-Jr, C. J. (Eds.). Check List of the Freshwater Fishes of South and Central America. Porto Alegre, Edipucrs, 729p.

Malabarba, M. C. 1998. Monophyly of the Cheirodontinae, characters and major clades (Ostariophysi: Characidae). Pp. 193-233. In: Malabarba, L. R., R. E. Reis, R. P. Vari, Z. M. S. Lucena \& C. A. S. Lucena (Eds.). Phylogeny and Classification of Neotropical Fishes. Porto Alegre, Edipucrs, 603p.

Malabarba, L. R. \& R. P. Vari. 2000. Caiapobrycon tucurui, a new genus and species of characid from the rio Tocantins basin, Brazil (Characiformes, Characidae). Ichthyological Exploration of Freshwaters, 11: 315-326.

Malabarba, L. R. \& S. H. Weitzman. 2003. Description of a new genus with six new species from southern Brazil, Uruguay and Argentina, with a discussion of a putative Characid clade (Teleostei: Characiformes: Characidae). Comunicações do Museu de Ciências e Tecnologia da PUCRS. Série Zoologia, 16: 67151.

Menezes, N. A. \& S. H. Weitzman. 2009. Systematics of the Neotropical fish subfamily Glandulocaudinae (Teleostei: Characiformes: Characidae). Neotropical Ichthyology, 7(3): 295370 .

Miquelarena, A. M. \& R. H. Arámburu, 1983. Osteologia y lepidologia de Gymnocharacinus bergi (Pisces: Characidae). Limnobios, 2(7): 491-512.

Mirande, J. M. 2009. Weighted parsimony phylogeny of the family Characidae (Teleostei: Characiformes). Cladistics, 25: 1-40.

Mirande, J. M. 2010. Phylogeny of the family Characidae (Teleostei: Characiformes): from characters to taxonomy. Neotropical Ichthyology, 8(3): 385-568. 
Oliveira, J. C. \& H. A. Britski. 2000. Redescrição de Taunaya bifasciata (Eigenmann \& Norris, 1900), combinação nova, um bagre enigmático do Estado de São Paulo (Siluriformes, Pimelodidae, Heptapterinae). Papéis Avulsos de Zoologia, 41: 119-133.

Reis, R. E., S. O. Kullander \& C. J. Ferraris-Jr. (Eds.). 2003. Checklist of the freshwater fishes of South and Central America. Porto Alegre, Edipucrs, 729p.

Ribeiro, A. C. 2006. Tectonic history and the biogeography of the freshwater fishes from the coastal drainages of eastern Brazil: an example of faunal evolution associated with a divergent continental margin. Neotropical Ichthyology, 4(2): 225-246.

Ribeiro, A. C., F. C. T. Lima, C. Riccomini \& N. A. Menezes. 2006. Fishes of the Atlantic Rainforest of Boracéia: testimonies of the Quaternary fault reactivation within a Neoproterozoic tectonic province in Southeastern Brazil. Ichthyological Exploration of Freshwaters, 17(2): 157-164.

Román-Valencia, C., H. J. Paepke \& F. Pantoja. 2003. Una especie nueva de Grundulus (Teleostei: Ostariophysi: Characidae) para Colombia y redescripción de Grundulus bogotensis (Humboldt y Valenceiennes, 1833). Memoria de la Fundación La Salle de Ciencias Naturales, 155: 51-72.

Román-Valencia, C., R. I. Ruiz C. \& R. Barriga. 2005. Una nueva especie ecuatoriana del género de peces andinos Grundulus (Characiformes: Characidae). Revista de Biología Tropical (International Journal of Tropical Biology and Conservation), 53(3-4): 537-544.

Serra, J. P., F. R. Carvalho \& F. Langeani. 2007. Ichthyofauna of the rio Itatinga in the Parque das Neblinas, Bertioga, São Paulo: composition and biogeography. Biota Neotropica 7(1): 131-136.

Serra, J. P. \& F. Langeani. 2006. Redescrição e osteologia de Bryconamericus exodon Eigenmann, 1907 (Ostariophysi, Characiformes, Characidae). Biota Neotropica, 6(2): 1-14.

Serra, J. P., F. Langeani, F. C. T. Lima \& I. Sazima. 2008. Coptobrycon bilineatus (Ellis, 1911). Pp 60-61. In: Machado, A. B. M., G. M. Drummond \& A. P. Paglia (Eds.). Livro Vermelho da Fauna Brasileira Ameaçada de Extinção. Biodiversidade 19. Ministério do Meio Ambiente, Brasília \& Fundação Biodiversitas, Belo Horizonte, 907p.
Taylor, W. R. \& G. C. van Dyke. 1985. Revised procedures for staining and clearing small fishes and other vertebrates for bone and cartilage study. Cybium, 9: 107-119.

Vari, R. P. 1995 The neotropical fish family Ctenoluciidae (Teleostei: Ostariophysi: Characiformes): supra and intrafamilial phylogenetic relationships, with a revisionary study. Smithsonian Contributions to Zoology, 564: 1-97.

Weitzman, S. H. 1962. The osteology of Brycon meeki, a generalized Characidae fish, with an osteological definition of the family. Stanford Ichthyological Bulletin, 8: 1-77.

Weitzman, S. H. 1974. Osteology and evolutionary relationships of the Sternoptychidae, with a new classification of stomiatoid families. Bulletin of the American Museum of Natural History, 153: 327-478.

Weitzman, S. H. \& W. L. Fink. 1983. Relationships of the neon tetras, a group of South American freshwater fishes (teleostei: Characidae), with comments on the phylogeny of New World characiforms. Bulletin of the Museum of Comparative Zoology, 150(6): 339-395.

Weitzman, S. H. \& S. V. Fink. 1985. Xenurobryconin phylogeny and putative pheromone pumps in glandulocaudine fishes (Teleostei: Characidae). Smithsonian Contributions to Zoology, 421: 1-121.

Weitzman, S. H. \& L. R. Malabarba. 1998. Perspectives about the phylogeny and classification of the Characidae (Teleostei: Characiformes). Pp. 161-170. In: Malabarba, L. R., R. E. Reis, R. P. Vari, Z. M. Lucena \& C. A. S. Lucena (Eds.). Phylogeny and Classification of Neotropical Fishes. Porto Alegre, Edipucrs, $603 \mathrm{p}$.

Weitzman, S. H. \& L. R. Malabarba. 1999. Systematics of Spintherobolus (Teleostei: Characidae: Cheirodontinae) from eastern Brazil. Ichthyological Exploration of Freshwaters, 10: $1-43$.

Zanata, A. M. \& R. P. Vari. 2005. The family Alestidae (Ostariophysi, Characiformes): a phylogenetic analysis of a trans-Atlantic clade. Zoological Journal of the Linnean Society, 145: 1-144. 